\title{
Central Composite Design Aided Formulation Development and Optimization of Clarythromycin Extended-Release Tablets
}

\author{
Haranath Chinthaginjala ${ }^{1, *}$, Hindustan Abdul Ahad ${ }^{1}$, Eranti Bhargav ${ }^{1}$, Bhupalam Pradeepkumar ${ }^{2}$ \\ ${ }^{1}$ Department of Industrial Pharmacy, Raghavendra Institute of Pharmaceutical Education and Research (RIPER)-Autonomous, \\ KR Palli Cross, Chiyyedu, Anantapur, Andhra Pradesh, INDIA. \\ 2Department of Pharmacology, Raghavendra Institute of Pharmaceutical Education and Research (RIPER)-Autonomous, KR Palli \\ Cross, Chiyyedu, Anantapur, Andhra Pradesh, INDIA.
}

\begin{abstract}
Objectives: The present work was designed to formulate extended-release tablets of clarithromycin by means of central composite design. To assess the systematic considerate of input and output variables and to construct design space, the central composited design was used. Methods: The concentrations of tamarind kernel powder $\left(X_{1}\right)$, ethyl cellulose $\left(X_{2}\right)$ and polyvinyl pyrrolidone $\left(X_{3}\right)$ remained as independent variables and responses were drug release in $2 \mathrm{~h}, 8 \mathrm{~h}$ and $\mathrm{t} 50 \%$. Polynomial equations were employed to forecast the quantitative result of nondependent constraints at different levels on responses. The model stood nonlinear and the curvature outcome was significant. Henceforth the study employed central composite design for optimization. Wet granulation method was used to prepare the tablets and were evaluated for pharmacotechnical properties. Results: FTIR and DSC studies signposted that drug and excipients were compatible. Precompression constraints specified respectable flow properties. The in vitro drug release of entire formulations at the end of $12 \mathrm{~h}$ was found to be $96.14 \%-98.23 \%$. Increase in the concentration of tamarind kernel powder, ethyl cellulose decreased percentage drug release. Contour plots were utilized to assess the relationship between independent variables and dependent variables. Conclusion: The statistical model is scientifically effective as the investigational estimates and foreseen estimates proposed by the model were relatively close to each other. The outcomes confirmed the success of the anticipated design for development of clarithromycin extended-release tablets with optimized properties.
\end{abstract}

Key words: Tamarind kernel powder, Ethyl cellulose, Polyvinyl pyrrolidone, Clarithromycin, Central composite design, Extended release.

\section{INTRODUCTION}

Extended release (ER) formulations can permit for lessening in dose frequency, which may boost suitability and thereby progress adherence. ${ }^{1}$ The ER preparations possibly will uphold therapeutic concentrations over extended periods. The practice of ER formulations circumvents the elevated blood concentrations and can possibly progress the patient consistence. ${ }^{2} \mathrm{ER}$ dosage form is the one that permits in any event a twofold decrease in dosage recurrence when contrasted with that medication introduced as an immediate-release. ${ }^{3}$ The clarithromycin drug is semi-synthetic macrolide antibiotic used to treat a variety of bacterial infections and extensively engaged in usual abolition treatment of gastric H. pylori infection and upper respiratory tract infections by preventing the bacteria by reducing the protein synthesis. ${ }^{4,5}$ The drug has short half-life of 3-4 h, which requires frequent administration with normal conventional dosage form causing large and undesirable fluctuations in plasma concentration and this shortens duration of action for providing adequate treatment. Henceforth
Submission Date: 02-07-2020; Revision Date: 21-12-2020; Accepted Date: 09-02-2021

DOI: 10.5530/ijper.55.2.77 Correspondence:

Dr. Haranath Chinthaginjala Department of Industrial Pharmacy, Raghavendra Institute of Pharmaceutical Education and Research (RIPER) -Autonomous, KR Palli cross, Chiyyedu (PO), Anantapur-515721, Andhra Pradesh, INDIA.

Phone no: +91 9959072207 Email id: haranathriper@ gmail.com

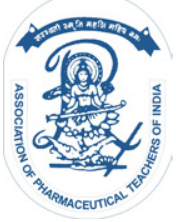

www.ijper.org 
this necessitates the formulation of ER of semisynthetic macrolide antibiotic that can be administered once or twice daily that can maintain therapeutic range of the drug. Design of Experiments (DoE) is broadly used for the application of $\mathrm{QbD}$ in both research and industrial backgrounds. Central Composite design (CCD) can fit a full quadratic model. CCD's are a factorial or fractional factorial design with center points, amplified with a group of axial points that let to estimate curvature and are specifically suitable in successive experiments which permits to shape on earlier factorial experiments. ${ }^{6}$ Optimization of a formulation or process is finding the finest probable composition or operating conditions. The persistence of optimization is to govern quantitatively the impact of the diverse factors collected on the response variables. ${ }^{7}$ By considering the numeral of factors, levels and probable interactions, the experimental designs were selected. The prime objective of the existing investigation is to formulate the ER tablets of clarithromycin by central composite design and to investigate the consequence of factors on the responses. The concentrations of tamarind kernel powder (TKP), Ethyl cellulose (EC) and Polyvinyl pyrrolidone (PVP) remained as factors and responses selected were drug release in $2 \mathrm{~h}, 8 \mathrm{~h}$ and $\mathrm{t}_{50 \%}$.

\section{MATERIALS AND METHODS}

Clarythromycin was offered as a free sample from Finoso Pharma Pvt Ltd, Hyderabad, Telangana. Ethyl Cellulose was purchased from SD Fine Chemicals, Mumbai. Avicel, PVP, Talc, Magnesium stearate and other chemicals were purchased from Loba Chemicals, Mumbai. All the chemicals used were of investigative grade.

\section{Preparation of tamarind kernel powder (TKP)}

TKP was prepared in accordance with the method described by Manchandana et al. $2014^{8}$

\section{FTIR studies}

FT-IR spectroscopy (FT IR- 8400-S Shimadzu, Japan) was engaged to determine the compatibility of drug with the excipients. ${ }^{9}$ Pure drug and excipients were mixed Potassium bromide and compressed into discs and were run over in the series of 4000 to $400 \mathrm{~cm}^{-1}$.

\section{DSC studies}

DSC studies were performed using DSC instrument (Mettler, Toledo) to determine the compatibility between the dug and excipients. Precisely gauged $3 \mathrm{mg}$ of drug alone and the blend containing excipients were transferred into aluminium crucible of the instrument and run over the temperature scope of 50 to $300^{\circ} \mathrm{C}$ by maintaining $10^{\circ} \mathrm{C} / \mathrm{min}$ of heating rate. ${ }^{10}$

\section{Optimization by the central composite design}

In the current research, Sigma Tech software Version 3.1 was used for the design of experimentation of clarithromycin tablets employing $2^{3}$ full factorial design with 4 replicates. ${ }^{11}$ The curvature effect was significant and the model was found to be nonlinear which suggested to central composite design for optimization. According to this design, each of the three factors was evaluated at three levels. The concentration of TKP $\left(\mathrm{X}_{1}\right)$, EC $\left(\mathrm{X}_{2}\right)$ and PVP $\left(\mathrm{X}_{3}\right)$ were designated as nondependent factors and percentage drug release in $2 \mathrm{~h}, 8 \mathrm{~h}$ and $\mathrm{t}_{50 \%}$ were selected as responses were tabulated in Table 1 and the experimental trials were represented in Table 2.

\section{Preparation of clarithromycin ER tablets}

Clarithromycin ER tablets were developed by wet granulation scheme. The entire formulation requirements were weighed in accordance with the composition as tabulated in Table $2.1 \& 2.2$ and screened via sieve no 40. The required quantities of Clarithromycin, tamarind kernel powder, ethyl cellulose were triturated in a mortar with pestle. To the above mixture PVP was added as binding agent and mixed well to obtain the wet mass. The granules were prepared by allowing the wet mass via sieve \#16 and then dried at $30^{\circ} \mathrm{C}$ for $1 \mathrm{~h} .{ }^{12}$ These dehydrated granules were screened using sieve \#22 and added with magnesium stearate and talc. Tablet compression machine (Rimek, India) was used to compress the granules into tablets.

\section{Precompression parameters \\ Bulk density (BD)}

The $\mathrm{BD}$ was assessed by transferring the correctly weighed mixture sample into the $100 \mathrm{ml}$ graduated cylinder by keeping it in a slanting position. The early volume and mass were recorded. Proportion of the mass to the volume it involved was calculated. ${ }^{13}$

\begin{tabular}{|c|c|c|c|c|c|c|}
\hline \multirow[t]{2}{*}{ Factors } & \multicolumn{5}{|c|}{ Actual values (\%w/w) } & \multirow[t]{2}{*}{ Response } \\
\hline & -2 & -1 & 0 & +1 & +2 & \\
\hline $\begin{array}{c}\mathrm{X}_{1} \\
\text { (TKP) }\end{array}$ & 5 & 7.5 & 10 & 12.5 & 15 & \multirow{3}{*}{$\begin{array}{c}\mathrm{Y} 1=\text { Drug } \\
\text { release at } 2 \mathrm{~h} \\
\mathrm{Y} 2=\text { Drug } \\
\text { release at } 8 \mathrm{~h} \\
\mathrm{Y} 3=\mathrm{t}_{50} \%\end{array}$} \\
\hline $\mathrm{X}_{2}(\mathrm{EC})$ & 1.25 & 3.25 & 5.25 & 7.25 & 9.25 & \\
\hline $\begin{array}{c}\mathrm{X}_{3} \\
\text { (PVP) }\end{array}$ & 2 & 2.75 & 3.5 & 4.25 & 5 & \\
\hline
\end{tabular}




\section{Table 2: Experimental design layout.}

\begin{tabular}{|c|c|c|c|c|c|}
\hline & Formulation code & Combinations & $\operatorname{TKP}\left(X_{1}\right)(\%)$ & $E C\left(X_{2}\right)(\%)$ & $\operatorname{PVP}\left(X_{3}\right)(\%)$ \\
\hline \multirow[t]{8}{*}{ Factorial Design } & $\mathrm{F} 1$ & 1 & 7.5 & 3.25 & 2.75 \\
\hline & $\mathrm{F} 2$ & $X_{1}$ & 12.5 & 3.25 & 2.75 \\
\hline & F3 & $\mathrm{X}_{2}$ & 7.5 & 7.25 & 2.75 \\
\hline & $\mathrm{F} 4$ & $\mathrm{X}_{1} \mathrm{X}_{2}$ & 12.5 & 7.25 & 2.75 \\
\hline & F5 & $\mathrm{X}_{3}$ & 7.5 & 3.25 & 4.25 \\
\hline & $\mathrm{F} 6$ & $\mathrm{X}_{1} \mathrm{X}_{3}$ & 12.5 & 3.25 & 4.25 \\
\hline & $\mathrm{F} 7$ & $\mathrm{X}_{2} \mathrm{X}_{3}$ & 7.5 & 7.25 & 4.25 \\
\hline & F8 & $\mathrm{X}_{1} \mathrm{X}_{2} \mathrm{X}_{3}$ & 12.5 & 7.25 & 4.25 \\
\hline \multirow[t]{4}{*}{ Mid-point } & F9 & Mid-point & 10.5 & 5.25 & 3.5 \\
\hline & F10 & Mid-point & 10.5 & 5.25 & 3.5 \\
\hline & F11 & Mid-point & 10.5 & 5.25 & 3.5 \\
\hline & F12 & Mid-point & 10.5 & 5.25 & 3.5 \\
\hline \multirow{6}{*}{$\begin{array}{c}\text { Central Composite } \\
\text { Design }\end{array}$} & F13 & $\mathrm{X}_{1} \mathrm{At}-2 \mathrm{~L}$ & 5.0 & 5.25 & 3.5 \\
\hline & F14 & $X_{1} A t+2 L$ & 15.0 & 5.25 & 3.5 \\
\hline & F15 & $\mathrm{X}_{2} \mathrm{At}-2 \mathrm{~L}$ & 10.0 & 1.25 & 3.5 \\
\hline & F16 & $X_{2} A t+2 L$ & 10.0 & 9.25 & 3.5 \\
\hline & F17 & $\mathrm{X}_{3} \mathrm{At}-2 \mathrm{~L}$ & 10.0 & 5.25 & 2 \\
\hline & F18 & $X_{3} A t+2 L$ & 10.0 & 5.25 & 5 \\
\hline
\end{tabular}

Table 2.1: Composition of formulation batches F1 - F9.

\begin{tabular}{|c|c|c|c|c|c|c|c|c|c|}
\hline $\begin{array}{c}\text { Ingredients } \\
\text { (Quantity in mg/tab) }\end{array}$ & F1 & F2 & F3 & F4 & F5 & F6 & F7 & F8 & F9 \\
\hline Clarithromycin & 250 & 250 & 250 & 250 & 250 & 250 & 250 & 250 & 250 \\
\hline Tamarind kernal powder & 37.5 & 62.5 & 37.5 & 62.5 & 37.5 & 62.5 & 37.5 & 62.5 & 50 \\
\hline Ethylcellulose & 16.25 & 16.25 & 36.25 & 36.25 & 16.25 & 16.25 & 36.25 & 36.25 & 26.25 \\
\hline PVP & 12.5 & 12.5 & 12.5 & 12.5 & 22.5 & 22.5 & 22.5 & 22.5 & 17.5 \\
\hline Avicel pH 101 & 173.7 & 148.7 & 153.7 & 128.7 & 163.7 & 138.7 & 143.7 & 118.75 & 146.25 \\
\hline Talc & 5 & 5 & 5 & 5 & 5 & 5 & 5 & 5 & 5 \\
\hline Magnesium stearate & 5 & 5 & 5 & 5 & 5 & 5 & 5 & 5 & 5 \\
\hline Total weight of the tablet(mg) & 500 & 500 & 500 & 500 & 500 & 500 & 500 & 500 & 500 \\
\hline
\end{tabular}

\section{Table 2.2: Composition of formulation batches F10 - F18.}

\begin{tabular}{|c|c|c|c|c|c|c|c|c|c|}
\hline Ingredients (Quantity in mg/tab) & F10 & F11 & F12 & F13 & F14 & F15 & F16 & F17 & F18 \\
\hline Clarithromycin & 250 & 250 & 250 & 250 & 250 & 250 & 250 & 250 & 250 \\
\hline Tamarind kernal powder & 50 & 50 & 50 & 25 & 75 & 50 & 50 & 50 & 50 \\
\hline Ethylcellulose & 26.25 & 26.25 & 26.25 & 26.25 & 26.25 & 6.25 & 46.25 & 26.25 & 26.25 \\
\hline PVP & 17.5 & 17.5 & 17.5 & 17.5 & 17.5 & 17.5 & 17.5 & 7.5 & 27.5 \\
\hline Avicel pH 101 & 146.25 & 146.25 & 146.25 & 171.25 & 121.25 & 166.25 & 126.25 & 156.25 & 146.25 \\
\hline Talc & 5 & 5 & 5 & 5 & 5 & 5 & 5 & 5 & 5 \\
\hline Magnesium stearate & 5 & 5 & 5 & 5 & 5 & 5 & 5 & 5 & 5 \\
\hline Total weight of the tablet(mg) & 500 & 500 & 500 & 500 & 500 & 500 & 500 & 500 & 500 \\
\hline
\end{tabular}




\section{Tapped density (TD)}

TD was examined by transferring the exactly weighed blend into $100 \mathrm{ml}$ measuring cylinder which was placed in tapped density apparatus (Electro lab). Cylinder having Initial volume $\left(\mathrm{V}_{0}\right)$ was recorded and was subjected to 100 times (tapping) measured the volume. ${ }^{14}$

\section{Compressibility index (CI)}

The $\mathrm{CI}$ is an indication of compressibility of a powder. ${ }^{15}$ It was calculated by the formula as below.

$\mathrm{CI}=\frac{\text { TDpre }}{\mathrm{TD}} \times \mathrm{app}$

\section{Hausner ratio (HR)}

HR is an ancillary guide of ease of powder flow. ${ }^{16}$ It was determined by the accompanying equation

$\mathrm{HR}=\mathrm{TD} / \mathrm{BD}$

\section{Angle of repose (AR)}

This is the modest technique for measuring the resistance to particle movement. AR is the extreme viewpoint probable amid the exterior of heap of powder and horizontal plane. ${ }^{17}$

$\operatorname{Tan} \Theta=h / r$

$\Theta=\tan ^{-1} h / r$

\section{Post compression parameters Weight variation}

The test was performed as per IP. Twenty tablets were chosen haphazardly from every formulation and weighed separately, assessed the average weight and standard deviation was determined. ${ }^{18}$

\section{Thickness}

Five tablets were casually drawn from individual formulations and thickness was assessed by means of vernier callipers. ${ }^{19}$

\section{Hardness}

Hardness of randomly selected tablets was examined via Monsanto tablet hardness tester. ${ }^{20}$ Five tablets from respective formulations were tested. It is expressed in $\mathrm{kg} / \mathrm{cm}^{2}$.

\section{Friability}

Tablets ten in number were weighed and positioned in the Roche friabilator apparatus and was run at $25 \mathrm{rpm}$ for 4 min. ${ }^{21}$ These tablets were de dusted and weighed again. The $\%$ friability was measured using

$\%$ Friability $=(\mathrm{M} 1-\mathrm{M} 2) / \mathrm{M} 1 \times 100$

where, M1 is the tablets weight prior to run and M2 is the tablets weight later run.

\section{Drug Content}

Phosphate buffer of $\mathrm{pH} 6.8$ was availed to find out the amount of drug present in one tablet. 10 tablets of respective formulations were crushed and fined. The Powder alike to $500 \mathrm{mg}$ of clarithromycin was weighed and liquified in Phosphate buffer in a $100 \mathrm{ml}$ volumetric flask. ${ }^{22}$ The resulting solution was analysed at $264 \mathrm{~nm}$ using UV Spectrophotometer.

\section{In vitro drug release (DR)}

In vitro DR of clarithromycin extended release tablets was assessed by means of USP dissolution test apparatus II (Paddle type) availing $900 \mathrm{ml}$ of $0.1 \mathrm{~N} \mathrm{HCl}$ in $2 \mathrm{~h}$, then shadowed by phosphate buffer of ( $\mathrm{pH}$ 6.8) maintained at $37 \pm 0.5^{\circ} \mathrm{C}$ with $100 \mathrm{RPM}$ of paddle. The samples were collected at defined time intervals. ${ }^{23}$ Aliquots from withdrawn were filtered and was analysed at $264 \mathrm{~nm}$ with UV spectrophotometer and DR was deliberated.

\section{Statistical analysis and optimization}

In order to generate the study design, the data gained from all the formulations were examined employing Sigma Tech software (version 3.1). As per the numerous statistical constraints comparison furnished by the Sigma Tech software, best-fit model was chosen. To identify noteworthy possessions of factors on response regression coefficients, ANOVA was used. Contour designs were applied to further explicate the connection amid the reliant and non-reliant constraints. To produce innovative formulations with the anticipated retorts a graphical optimization system with contour plots were engaged and were evaluated for drug release at $2 \mathrm{~h}, 8$ $\mathrm{h}$ and $\mathrm{t}_{50 \%}$ to verify the theoretical prediction. The relative errors (RE) (\%) amongst the projected and investigational results for individual response were calculated.

\section{RESULTS AND DISCUSSION}

FT-IR spectroscopy showed that the major distinctive crests of unadulterated drug and blend were retained in the spectra which ensures that the compatibility of drug with the excipients used (Figure 1 and 2). In the spectra of clarythromycin wave numbers were recorded at $3467.77,3475.47$ and $1730.90 \mathrm{~cm}^{-1}$ which resembled to $\mathrm{O}-\mathrm{H}$ stretching, $\mathrm{N}-\mathrm{H}$ stretching and $\mathrm{C}=\mathrm{O}$ stretching. DSC thermograms of pure drug and blend reveals that no key modification in the position of the melting peak of drug (Figure 3) which suggests the drug and polymers used in the study are compatible. The bulk density of the all formulations (F1-F18) were found to be in the range of $0.41 \pm 0.07$ to $0.55 \pm 0.04$. The TD 


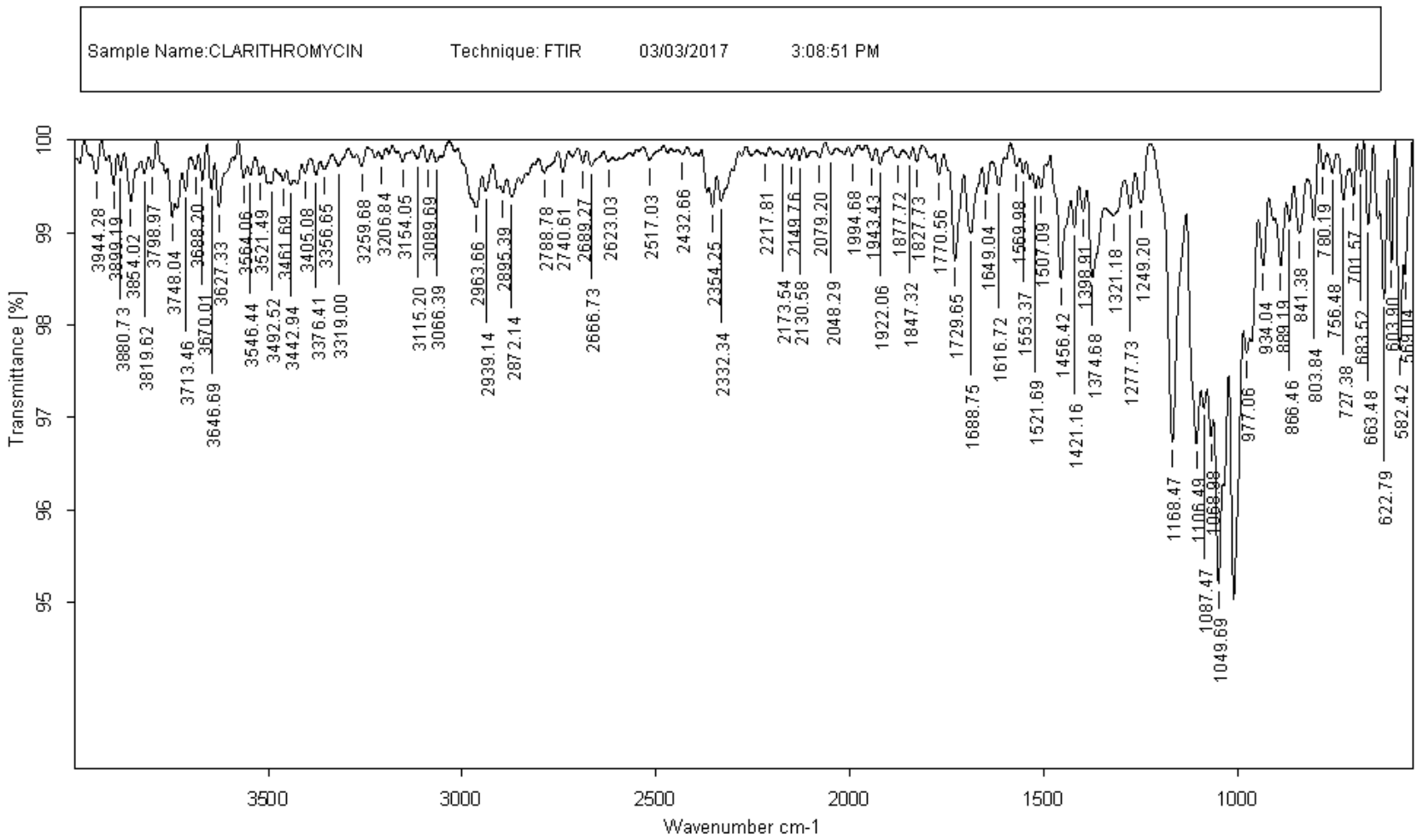

Figure 1: FT-IR spectra of clarithromycin.

of the all formulations (F1-F18) stood in the score of $0.47 \pm 0.04$ to $0.62 \pm 0.07$. The angle of repose was found in between $20.35^{\circ}-25.41^{\circ}$. The CI and HR was in the range of $10.63 \pm 0.02 \%$ to $15.00 \pm 0.06 \%$ and $1.11 \pm 0.03$ to $1.17 \pm 0.04$ which ensures good flow properties and the values were shown in Table 3 .

The average weight of the all formulations was found to be within $\pm 5 \%$ deviation as per the IP specifications. The thickness and hardness of the all formulations were found to be $6.61 \pm 0.4$ to $6.69 \pm 0.1 \mathrm{~mm}$ and $7.9-9.0 \mathrm{~kg} /$ $\mathrm{cm}^{2}$. The friability of entire formulations was less than $0.5 \%$, which ensures good mechanical strength of the tablets. The drug content of (F1-F18) was found to be $95.6 \pm 0.45-99.50 \pm 0.37$ and was depicted in Table 4 . The in vitro DR of all formulations at $2 \mathrm{~h}, 8 \mathrm{~h}$ and $12 \mathrm{~h}$ was found to be $20.14 \%-37.36 \%, 66.24 \%-85.57 \%$ and $96.14 \%-98.23 \%$ (Figure 4).

In vitro drug release data at $2 \mathrm{~h}(\mathrm{Y} 1)$ was analysed and found that interaction of $\mathrm{X} 1, \mathrm{X} 2, \mathrm{X} 3$ was uppermost with SS ratio $(35.9483 \%)$ and a positive sign of the coefficient (2.6) represented in Table 5.

Ultimate equation of coded factors
$\mathrm{Y} 1=27.0128-0.7006 . \mathrm{X}_{1}-0.669 \mathrm{X}_{2}+0.2169 . \mathrm{X}_{3}+$ $2.1062 \mathrm{X}_{1} \mathrm{X}_{2}+1.7287 \mathrm{X}_{1} \mathrm{X}_{3}+1.5513 \mathrm{X}_{2} \mathrm{X}_{3}-0.5885 \mathrm{X}_{1}^{2}$ $0.851 \mathrm{X}_{2}^{2}-0.7585 \mathrm{X}_{3}^{2}$

\section{Ultimate equation of actual factors}

$\mathrm{Y} 1=27.0128-0.7006 . \mathrm{TKP}-0.669 \mathrm{EC}+0.2169$. PVP + 2.1062 TKP.EC+ 1.7287 TKP. PVP + 1.5513 EC.PVP - $0.5885(\text { TKP })^{2}-0.851(\mathrm{EC})^{2}-0.7585(\mathrm{PVP})^{2}$ ANOVA was availed to recognize significant effect of the factors on the response. Obtained value of $F$ is greater than critical $F$-value, the result was found to be significant at that level of probability $(\phi<0.05)$ as shown in Table 6. The critical value of $F$ is 4.95 , obtained $F$ value (i.e. 10.1) is larger than critical value and so it can be resolved that attained $F$ value is expected to happen by chance with a $p<0.05$. Subsequently the association between $\mathrm{Y}_{1} \mathrm{Vs}_{1} \mathrm{X}_{1} \mathrm{X}_{3}$ is nonlinear as shown by Sigma Tech software, the CCD has been implemented. The results of the multiple linear regression analysis revealed that the increase in the amount of $\mathrm{X}_{1}, \mathrm{X}_{2}, \mathrm{X}_{3}$ increased the DR at $2 \mathrm{~h} .{ }^{24}$ All the three factors exhibited significant interactions.

In vitro drug release data at $8 \mathrm{~h}\left(\mathrm{Y}_{2}\right)$ was ascertained and observed that interaction of $\mathrm{X}_{2}$ was maximum with SS 
CENTRE FOR PHARMACEUTICAL RESEARCH (CPR)

RAGHAVENDRA INSTITUTE OF PHARMACEUTICAL EDUCATION AND RESEARCH (RIPER), Anantapur, (AP) . India bimister

Sample Name:CLARITHROMYCIN form Technique: FTIR $\quad 03 / 03 / 2017 \quad 2: 58: 22 \mathrm{PM}$

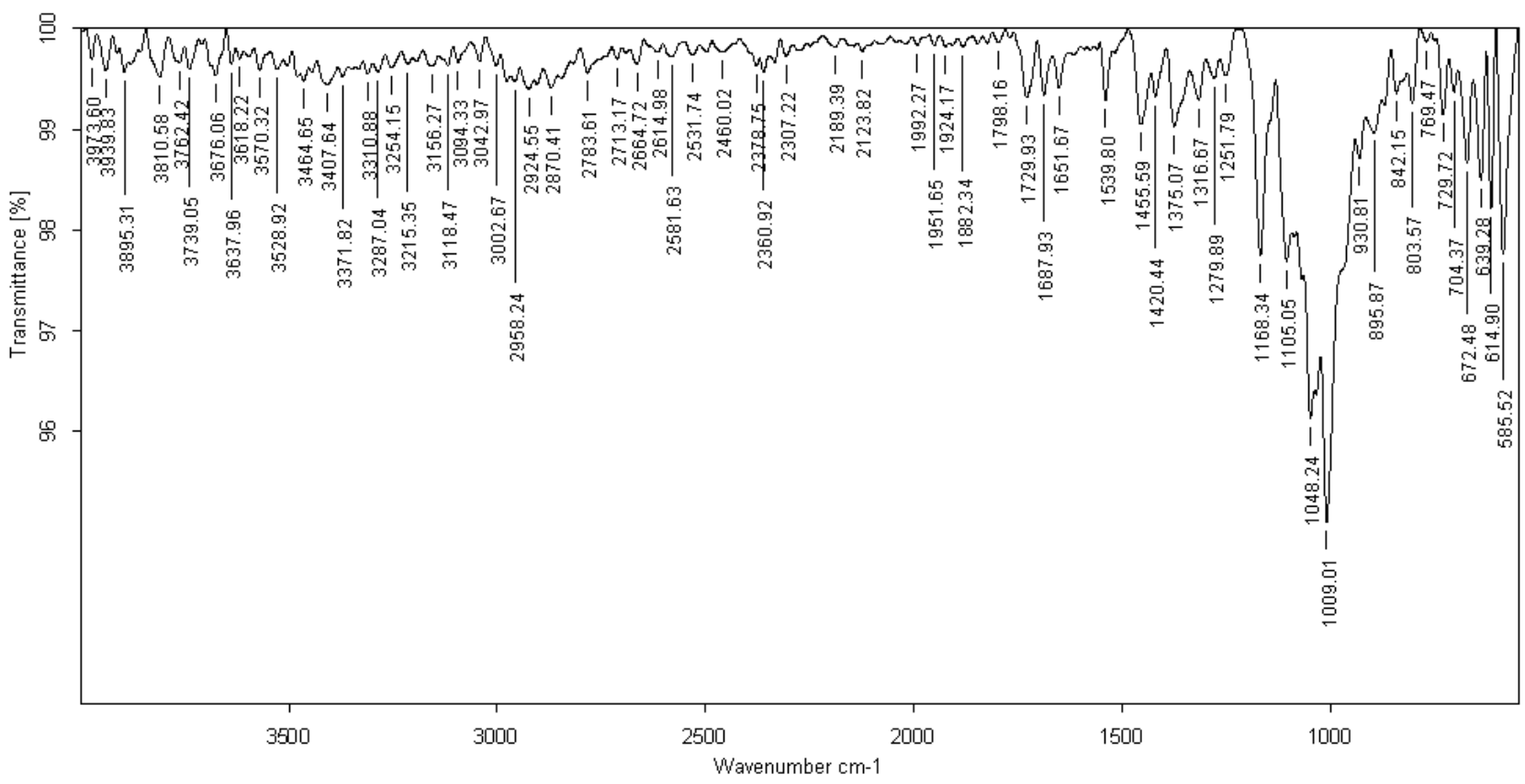

Figure 2: FT-IR spectra of clarythromycin with excipients
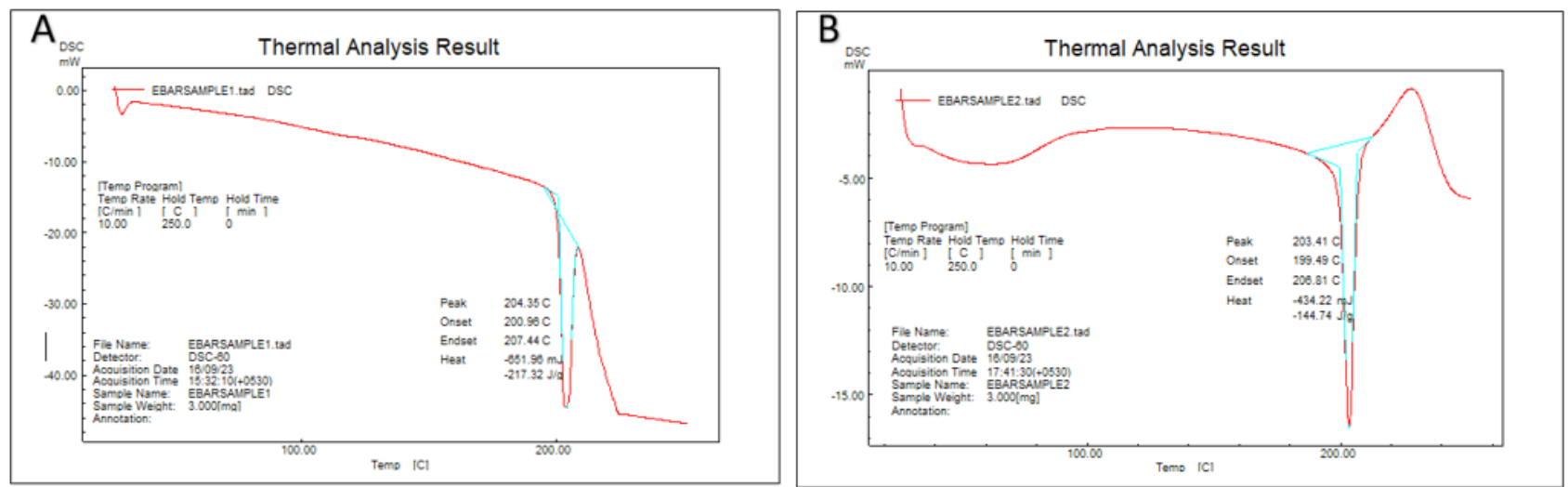

Figure 3: DSC thermograms A) clarythromycin B) clarythromycin with excipients.

ratio (44.8271\%) and a negative sign of the coefficient (-2.6637). It specified that the rise in the quantity of $\mathrm{X}_{2}$ decreased the DR and the data was tabulated in Table 7. ANOVA was availed to categorize significant effect and the results were shown in Table 8 .

\section{Final equation in terms of coded factors}

$\left(\mathrm{Y}_{2}\right)=78.9451-0.3869 \mathrm{X}_{1}-1.6594 \mathrm{X}_{2}-1.5756 \mathrm{X}_{3}-$ $0.3313 \mathrm{X}_{1} \mathrm{X}_{2}+0.0813 \mathrm{X}_{1} \mathrm{X}_{3}+1.2687 \mathrm{X}_{2} \mathrm{X}_{3}-1.0016 \mathrm{X}_{1}^{2}$ $-1.7629 \mathrm{X}_{2}^{2}-1.2279 \mathrm{X}_{3}^{2}$
Final equation in terms of actual factors

$\mathrm{Y} 2=78.9451-0.3869 \mathrm{TKP}-1.6594 \mathrm{EC}-1.5756 \mathrm{PVP}$ -0.3313 TKP.EC + 0.0813 TKP.PVP + 1.2687 EC.PVP $-1.0016(\mathrm{TKP})^{2}-1.7629(\mathrm{EC})^{2}-1.2279(\mathrm{PVP})^{2}$

The polynomial equations were engaged to furnish conclusions subsequently in view of the magnitude of the coefficient and the mathematical sign it possess (i.e., positive or negative). The outcomes of the multiple linear regression analysis exposed that DR decreased with an upsurge in the ethyl cellulose. ${ }^{25}$ 


\begin{tabular}{|c|c|c|c|c|c|}
\hline Formulations & $\begin{array}{c}\text { Angle of } \\
\text { repose }\left({ }^{0}\right) \pm S D^{*}\end{array}$ & $\begin{array}{l}\text { Bulk density } \\
\mathrm{gm} / \mathrm{cm}^{3} \pm S D^{*}\end{array}$ & $\begin{array}{c}\text { Tapped density } \\
\text { (gm/cm3) } \\
\pm \mathrm{SD}^{*}\end{array}$ & $\begin{array}{c}\text { Carr's index } \\
(\%) \\
\pm \mathrm{SD}^{*}\end{array}$ & $\begin{array}{c}\text { Hausner ratio } \\
\pm S D^{*}\end{array}$ \\
\hline $\mathrm{F} 1$ & $24.2 \pm 0.07$ & $0.55 \pm 0.04$ & $0.62 \pm 0.05$ & $11.66 \pm 0.09$ & $1.12 \pm 0.05$ \\
\hline F2 & $25.41 \pm 0.06$ & $0.54 \pm 0.03$ & $0.61 \pm 0.07$ & $11.47 \pm 0.08$ & $1.12 \pm 0.05$ \\
\hline F3 & $24.35 \pm 0.07$ & $0.51 \pm 0.02$ & $0.60 \pm 0.05$ & $15.00 \pm 0.06$ & $1.17 \pm 0.04$ \\
\hline F4 & $21.28 \pm 0.04$ & $0.53 \pm 0.05$ & $0.62 \pm 0.07$ & $14.51 \pm 0.04$ & $1.16 \pm 0.04$ \\
\hline F5 & $20.84 \pm 0.02$ & $0.52 \pm 0.02$ & $0.59 \pm 0.04$ & $11.86 \pm 0.02$ & $1.13 \pm 0.03$ \\
\hline F6 & $25.21 \pm 0.02$ & $0.47 \pm 0.03$ & $0.55 \pm 0.01$ & $14.54 \pm 0.01$ & $1.17 \pm 0.03$ \\
\hline F7 & $23.26 \pm 0.01$ & $0.46 \pm 0.04$ & $0.54 \pm 0.02$ & $14.81 \pm 0.02$ & $1.17 \pm 0.02$ \\
\hline F8 & $22.51 \pm 0.01$ & $0.48 \pm 0.06$ & $0.55 \pm 0.04$ & $14.58 \pm 0.02$ & $1.14 \pm 0.02$ \\
\hline F9 & $24.31 \pm 0.06$ & $0.42 \pm 0.07$ & $0.47 \pm 0.04$ & $10.63 \pm 0.05$ & $1.11 \pm 0.03$ \\
\hline F10 & $20.35 \pm 0.04$ & $0.42 \pm 0.07$ & $0.48 \pm 0.04$ & $12.45 \pm 0.05$ & $1.14 \pm 0.03$ \\
\hline F11 & $24.63 \pm 0.02$ & $0.41 \pm 0.07$ & $0.47 \pm 0.04$ & $12.76 \pm 0.05$ & $1.14 \pm 0.03$ \\
\hline $\mathrm{F} 12$ & $20.39 \pm 0.08$ & $0.42 \pm 0.07$ & $0.49 \pm 0.04$ & $14.28 \pm 0.05$ & $1.16 \pm 0.03$ \\
\hline F13 & $25.12 \pm 0.03$ & $0.49 \pm 0.04$ & $0.56 \pm 0.06$ & $12.50 \pm 0.06$ & $1.14 \pm 0.05$ \\
\hline F14 & $21.64 \pm 0.01$ & $0.48 \pm 0.02$ & $0.54 \pm 0.07$ & $11.11 \pm 0.02$ & $1.12 \pm 0.06$ \\
\hline F15 & $25.17 \pm 0.01$ & $0.51 \pm 0.02$ & $0.60 \pm 0.02$ & $15.00 \pm 0.01$ & $1.17 \pm 0.03$ \\
\hline F16 & $21.25 \pm 0.03$ & $0.47 \pm 0.07$ & $0.55 \pm 0.06$ & $14.54 \pm 0.06$ & $1.17 \pm 0.04$ \\
\hline F17 & $21.11 \pm 0.04$ & $0.51 \pm 0.03$ & $0.59 \pm 0.03$ & $13.55 \pm 0.02$ & $1.15 \pm 0.03$ \\
\hline F18 & $24.89 \pm 0.04$ & $0.51 \pm 0.02$ & $0.58 \pm 0.02$ & $12.06 \pm 0.04$ & $1.13 \pm 0.02$ \\
\hline
\end{tabular}

All values are expressed as mean \pm standard deviation $(n=3)$

\section{Table 4: Post compression parameters of F1-F18 formulations.}

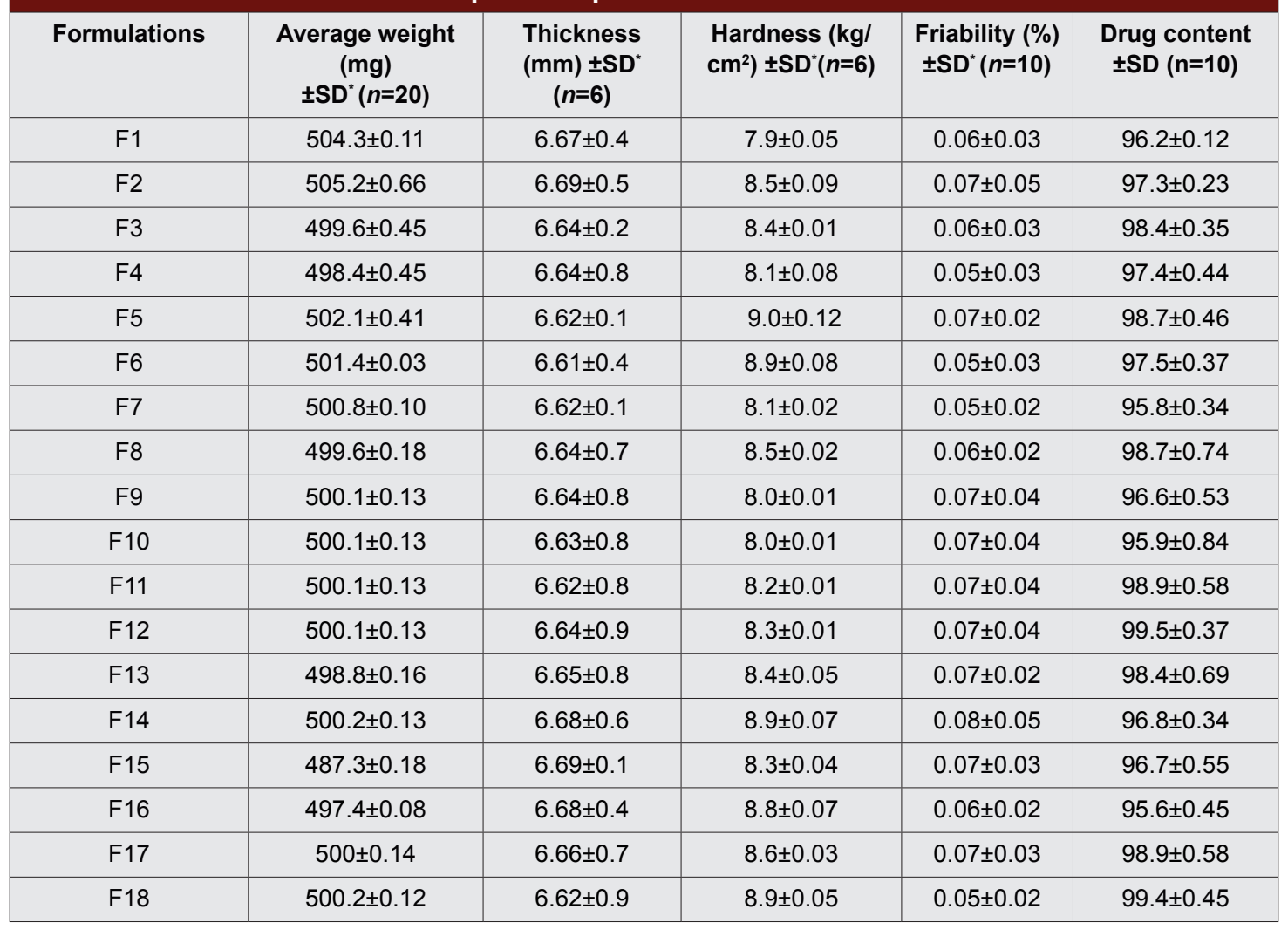

All values are expressed as mean \pm standard deviation $(n=3)$ 


\section{Table 5: Statistical analysis of DOE experimental} observations for response $\mathrm{Y} 1$ (2h).

\begin{tabular}{|c|c|c|c|c|}
\hline S N0. & Combination & Coefficient & F-value & SS ratio \\
\hline 1 & B0 & 27.4638 & 0.0 & $\ldots$ \\
\hline 2 & B1 & -1.4462 & 17.22281 & $10.4004 \%$ \\
\hline 3 & B2 & -0.8538 & 6.0047 & $3.625 \%$ \\
\hline 4 & B12 & 2.1062 & 36.541 & $22.0593 \%$ \\
\hline 5 & B3 & 0.4787 & 1.8876 & $1.1395 \%$ \\
\hline 6 & B13 & 1.7287 & 24.6162 & $14.8605 \%$ \\
\hline 7 & B23 & 1.5513 & 19.8232 & $11.967 \%$ \\
\hline 8 & B123 & 2.6 & 34.3543 & $35.9483 \%$ \\
\hline
\end{tabular}

$F$ is Fisher's value, SS is Sum of squares

\section{Table 7: Statistical analysis of DOE experimental} observations for response Y2 (8h).

\begin{tabular}{|c|c|c|c|c|}
\hline S NO & Combination & Coefficient & F-VALUE & SS Ratio \\
\hline 1 & B0 & 79.29 & 0.0 & $\ldots$ \\
\hline 2 & B1 & -1.0613 & 2.9814 & $7.1162 \%$ \\
\hline 3 & B2 & -2.6637 & 18.7806 & $44.8271 \%$ \\
\hline 4 & B12 & -0.3313 & 0.2905 & $0.6934 \%$ \\
\hline 5 & B3 & -2.2513 & 13.4154 & $32.021 \%$ \\
\hline 6 & B13 & 0.0813 & 0.0175 & $0.041 \%$ \\
\hline 7 & B23 & 1.2687 & 4.2605 & $10.1692 \%$ \\
\hline 8 & B123 & 0.9012 & 2.1497 & $5.1311 \%$ \\
\hline
\end{tabular}

\begin{tabular}{|c|c|c|c|c|c|c|c|c|}
\hline $\begin{array}{c}\text { S } \\
\text { NO }\end{array}$ & $\begin{array}{l}\text { Source of } \\
\text { Variance }\end{array}$ & ss & DF & MS & F-value & $\begin{array}{c}\text { F-std } \\
0.1 p\end{array}$ & $\begin{array}{l}\text { F-std } \\
0.05 p\end{array}$ & $\begin{array}{l}\text { F-std } \\
0.01 p\end{array}$ \\
\hline 1 & Model & 103.0477 & 6 & 17.1746 & 1.4548 & 3.4 & 4.95 & 10.7 \\
\hline 2 & Error & 57.835 & 5 & 11.567 & & & & \\
\hline 3 & Total & 160.8827 & 11 & & & & & \\
\hline \multicolumn{9}{|c|}{ 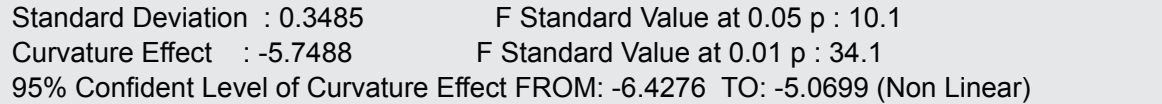 } \\
\hline
\end{tabular}

DF is Degrees of freedom, MS is mean squares, $\mathrm{P}$ is probability
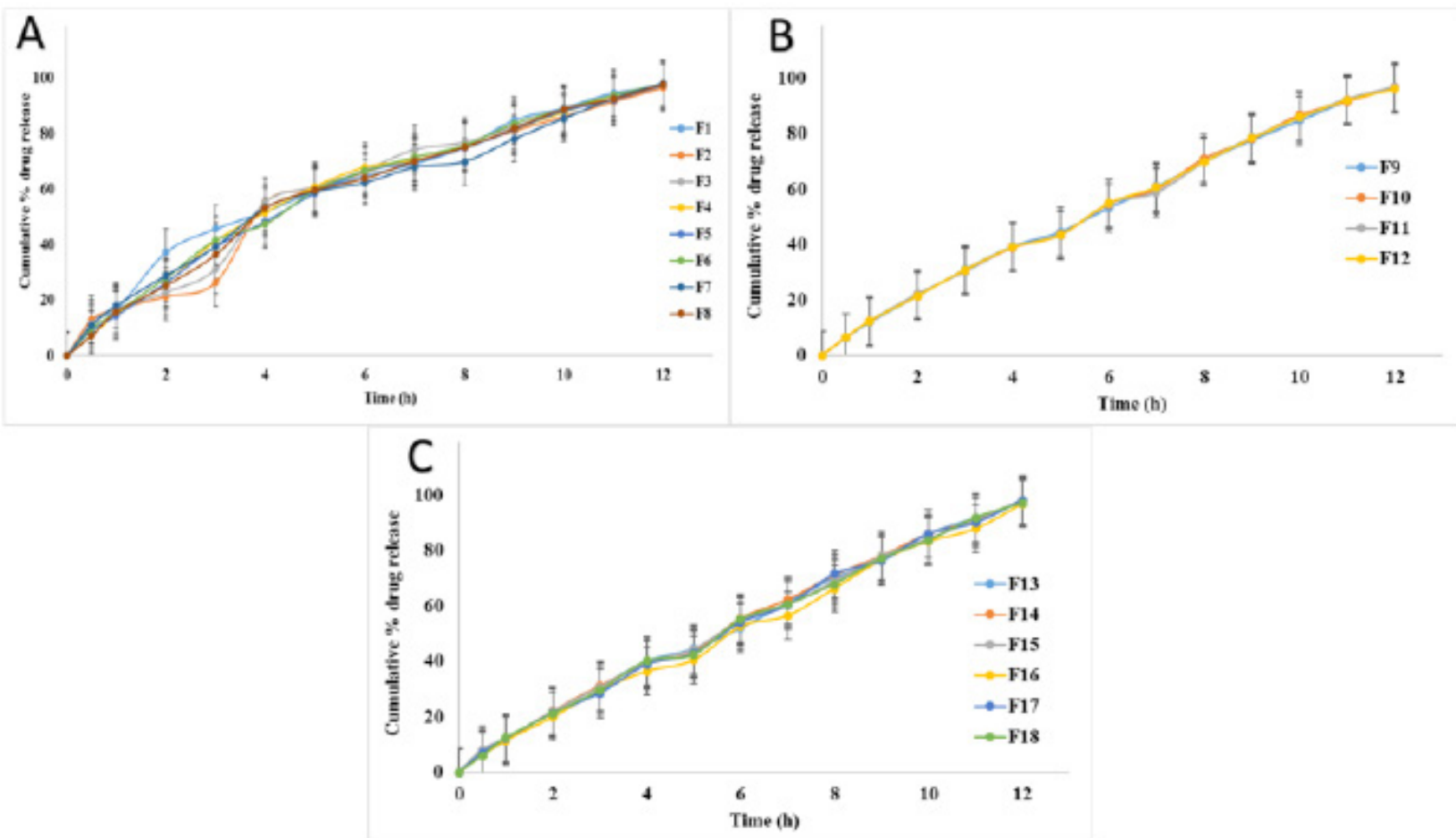

Figure 4: In vitro drug release profile of formulations A) F1-F8, B) F9 - F12 C) F13 - F18. 
Time to dissolve 50 percent of the drug, $\mathrm{t}_{50}$ data $\left(\mathrm{Y}_{3}\right)$ was scrutinized and noticed that interaction of X2 X3 was peak with SS ratio (53.1915\%) and a negative sign of the coefficient $(-0.125)$. and the data was represented in Table 9.

\section{Final equation in terms of coded factors}

$\left(\mathrm{Y}_{3}\right)=4.1333+0.1 \mathrm{X}_{1}+0.0125 \mathrm{X}_{2}+0.0375 \mathrm{X}_{3}+0.05$

$\mathrm{X}_{1} \mathrm{X}_{2}+0.0 \mathrm{X}_{1} \mathrm{X}_{3}-0.125 \mathrm{X}_{2} \mathrm{X}_{3}+0.0833 \mathrm{X}_{1}^{2}+0.2083$ $\mathrm{X}_{2}^{2}+0.1833 \mathrm{X}_{3}^{2}$

\section{Final equation in terms of actual factors}

$\mathrm{Y} 3=4.1333+0.1 \mathrm{TKP}+0.0125 \mathrm{EC}+0.0375 \mathrm{PVP}+$ 0.05 TKP.EC + 0.0 TKP.PVP -0.125 EC.PVP + 0.0833 $(\mathrm{TKP})^{2}+0.2083(\mathrm{EC})^{2}+0.1833(\mathrm{PVP})^{2}$

It was noticed that $t_{50}$ time increased with rise in concentrations of EC and $\mathrm{PVP}^{26}$ and the ANOVA was used to identify significant effect and data was shown in Table 10.
From contour plots it was found that suitable design space for drug release was found between the coded values as illustrated in Figure 5. The study lead to the design space from multidimensional combination of 2 $\mathrm{h}, 8 \mathrm{~h}$ and $\mathrm{t}_{50}$ that lead to the acceptable operating ranges for formulating extended release tablets. By considering the predicted values the formulation was prepared and examined for the responses. Contour plots allowed the configuration of TKP as $50 \mathrm{mg}(0)$ and Ethyl cellulose $26.25 \mathrm{mg}(0)$ and Polyvinyl pyrrolidone $13.75 \mathrm{mg}(-1)$; and all other ingredients remained same for optimized formulation. The RE amongst the prophesied and investigational values for individual outcome were calculated and results was noticed to be $0.28 \%, 0.43 \%$, $0.20 \%$ represented in Table 11 . The investigational values were in promise with the prophesied values authorizing the expectedness and strength of the model.

\begin{tabular}{|c|c|c|c|c|c|c|c|c|}
\hline \multicolumn{7}{|c|}{ Table 8: Results of ANOVA for response Y2 (8 h). } \\
\hline S NO & $\begin{array}{c}\text { Source of } \\
\text { Variance }\end{array}$ & SS & DF & MS & F-Value & $\begin{array}{c}\text { F-std } \\
\mathbf{0 . 1 p}\end{array}$ & $\begin{array}{c}\text { F-std } \\
\mathbf{0 . 0 5 p}\end{array}$ & $\begin{array}{c}\text { F-std } \\
\mathbf{0 . 0 1 p}\end{array}$ \\
\hline 1 & Model & 120.1279 & 6 & 20.0213 & 15.4057 & 3.4 & 4.95 & 10.7 \\
\hline 2 & Error & 6.498 & 5 & 1.2996 & & & & \\
\hline 3 & Total & 126.625 & 11 & & & & & \\
\hline
\end{tabular}

Standard Deviation : 0.6146

Curvature Effect :-9.0383

F Standard value at $0.05 p: 10.1$

95\% Confident Level of curvature effect FROM : -10.2356 TO : -7.8409 (Non Linear)

Table 9: Statistical analysis of DOE experimental observations for response $\mathrm{Y} 3\left(\mathrm{t}_{50 \%}\right)$.

\begin{tabular}{|c|c|c|c|c|}
\hline S NO & Combination & Coefficient & F-VALUE & SS Ratio \\
\hline 1 & B0 & 3.875 & 0.0 & $\ldots$ \\
\hline 2 & B1 & 0.0 & 0.0 & $0.0 \%$ \\
\hline 3 & B2 & -0.075 & 2.25 & $19.1489 \%$ \\
\hline 4 & B12 & 0.05 & 1.0 & $8.5106 \%$ \\
\hline 5 & B3 & 0.075 & 2.25 & $19.1489 \%$ \\
\hline 6 & B13 & 0.0 & 0.0 & $0.0 \%$ \\
\hline 7 & B23 & -0.125 & 6.25 & $53.1915 \%$ \\
\hline 8 & B123 & 0.0 & 0.0 & $0.0 \%$ \\
\hline
\end{tabular}

\begin{tabular}{|c|c|c|c|c|c|c|c|c|}
\hline \multicolumn{7}{|c|}{ Table 10: Results of ANOVA for response Y3 $\mathbf{( t}_{\mathbf{5 0 \%}}$ ). } \\
\hline S NO & $\begin{array}{c}\text { Source of } \\
\text { Variance }\end{array}$ & SS & CF & MS & F-Value & $\begin{array}{c}\text { F-std } \\
\mathbf{0 . 1 p}\end{array}$ & $\begin{array}{c}\text { F-std } \\
\mathbf{0 . 0 5 p}\end{array}$ & $\begin{array}{c}\text { F-std } \\
\mathbf{0 . 0 1 p}\end{array}$ \\
\hline 1 & Model & 0.235 & 6 & 0.0392 & 9.22337 & 3.4 & 4.95 & 10.7 \\
\hline 2 & Error & 0.0 & 5 & 0.0 & & & & \\
\hline 3 & Total & 0.235 & 11 & & & & & \\
\hline
\end{tabular}

Standard Deviation: $0.05 \mathrm{~F}$ Standard value at $0.05 \mathrm{p}: 10.1$

Curvature Effect: $1.7 \mathrm{FS}$ Standard value at $0.01 \mathrm{p}: 34.1$

$95 \%$ Confident level of curvature effect FROM: 1.6026 TO 1.7974 (Non Linear) 
Table 11: Comparison of experimental results with predicted responses of clarithromycin extended release tablets formulation.

\begin{tabular}{|c|c|c|c|c|c|}
\hline Ingredient & $\begin{array}{c}\text { Composition } \\
(\% / t a b)\end{array}$ & Response & $\begin{array}{c}\text { Predicted } \\
\text { value }\end{array}$ & $\begin{array}{c}\text { Experimental } \\
\text { Value }\end{array}$ & $\begin{array}{c}\text { Standard } \\
\text { Error (\%) }\end{array}$ \\
\hline TKP & 10 & $\begin{array}{c}\text { Y1 }(2 \mathrm{hr}) \\
(\%)\end{array}$ & 23.54 & 22.98 & 0.28 \\
\hline EC & 5.25 & $\begin{array}{c}\text { Y2 }(8 \mathrm{hr}) \\
(\%)\end{array}$ & 70.88 & 70.02 & 0.43 \\
\hline PVP & 2.75 & $\mathrm{Y} 3\left(\mathrm{t}_{50}\right)$ & 5.27 & 4.87 & 0.20 \\
\hline
\end{tabular}

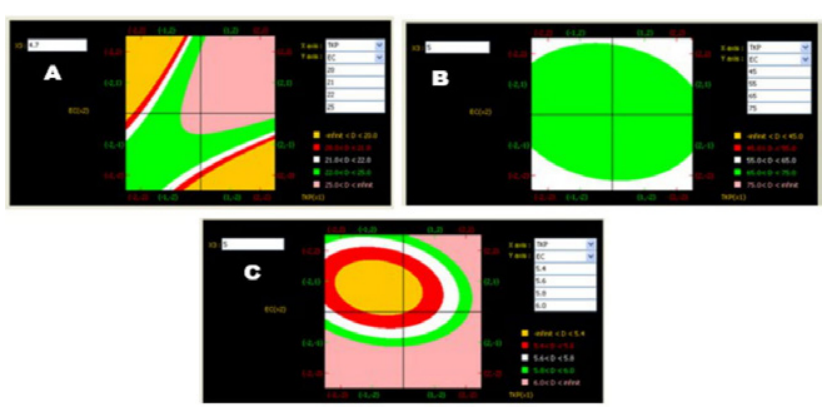

Figure 5: Contour plots A) Drug release at $2 \mathrm{~h} \mathrm{~B}$ ) Drug release at $8 \mathrm{~h} \mathrm{C)} \mathrm{t}_{50} \%$.

\section{CONCLUSION}

Clarythromycin ER tablets were successfully prepared by wet granulation method to overcome the frequency of intake of tablets. The concentration of variables was observed to have a deep and conjunct outcome on the dissolution of $2 \mathrm{~h}, 8 \mathrm{~h}, \mathrm{t}_{50}$ as shown by the model obtained using central composite design. The data exhibited that investigational plan was efficaciously enforced to augment the concentration of polymers to formulate extended release tablets with necessary release of drug at $2 \mathrm{~h}, 8 \mathrm{~h}, \mathrm{t}_{50}$. and also clinched that the central CCD might be effectively useful meant for the buildout of clarithromycin extended release tablets with less trials and improved value characteristics.

\section{ACKNOWLEDGEMENT}

The authors are thankful for DST-FIST faculty of Raghavendra Institute of Pharmaceutical Education and Research (RIPER) -Autonomous, Anantapur, AP, India for the provided support of experimental part.

\section{CONFLICT OF INTEREST}

The authors declare no conflicts of interest.

\section{ABBREVIATIONS}

ER: Extended release; DoE: Design of Experiments; CCD: Central Composite design; TKP: Tamarind kernel powder; EC: Ethyl cellulose; PVP: Polyvinyl pyrrolidone; $\boldsymbol{H}$. pylori: Helicobacter Pylori; FTIR: Fourier-transform infrared spectroscopy; DSC: Differential scanning calorimetry; IP: Indian Pharmacopoeia; UV::Ultraviolet; $\mathbf{H C l}$ : Hydrochloric acid; RPM: Revolutions per minute; ANOVA: Analysis of variance; SS ratio: Sum of squares ratio; RE: Relative error.

\section{REFERENCES}

1. Wheless JW, Phelps SJ. A Clinician's Guide to Oral Extended-Release Drug Delivery Systems in Epilepsy. The Journal of Pediatric Pharmacology and Therapeutics. 2018;23(4):277-92.

2. Reddy DV, Rao AS. A Review on Oral Extended Release Technology. Research Journal of Pharmacy and Technology. 2015;8(10):1454-62.

3. Shargel L, Yu AB. Modified release drug products. Applied Biopharmaceutics and Pharmacokinetics. 4th ed. McGraw Hill. 1999;169-71.

4. Leung WK, Graham DY. Clarithromycin for Helicobacter pylori infection. Expert Opinion on Pharmacotherapy. 2000;1(3):507-14.

5. Darkes MJ, Perry CM. Clarithromycin Extended-Release Tablet. American Journal of Respiratory Medicine. 2003;2(2):175-201.

6. Gujral G, Kapoor D, Jaimini M. An updated review on design of experiment (DOE) in pharmaceuticals. Journal of Drug Delivery and Therapeutics. 2018;8(3):147-52.

7. Jethara SI, Patel MR. Optimizing oral controlled release drug delivery systems using experimental designs. Intellectual Property Rights. 2015;28(1):1-6.

8. Manchanda R, Arora SC, Manchanda R. Tamarind seed polysaccharide and its modifications-versatile pharmaceutical excipients: A review. Int J Pharm Technol Res. 2014;6(2):412-20.

9. Sahadevan JT, Prabhakaran R, Vijay J, Gilhotra RM. Formulation and evaluation of cephalexin extended-release matrix tablets using hydroxy propyl methyl cellulose as rate-controlling polymer. Journal of Young Pharmacists. 2012;4(1):3-12.

10. Ramezani V, Vatanara A, Najafabadi AR, Moghaddam SP. Clarithromycin dissolution enhancement by preparation of aqueous nanosuspensions using sonoprecipitation technique. Iranian Journal of Pharmaceutical Research. 2014;13(3):809

11. Bhargav E, Reddy CS, Sowmya C, Haranath C, Khan KA, Rajesh K, et al. Formulation and optimization of piroxicam orodispersible tablets by central Composite design. Journal of Young Pharmacists. 2017;9(2):187.

12. Sekharan TR, Palanichamy S, Tamilvanan S, Shanmuganathan S, Thirupathi AT. Formulation and evaluation of hydroxypropyl methylcellulosebased controlled release matrix tablets for theophylline. Indian Journal of Pharmaceutical Sciences. 2011;73(4):451.

13. Haranath C, Reddy CS, Kumar BP, Khan KA. Formulation and in vitro evaluation of fast dissolving tablets of lacosamide using natural super disintegrants. Int J Pharm Sci and Res. 2019;10(6):2769-76. 
14. Karkala VP, Jinadatharaya H, Gowda DV, Sivadasu P. Development and Evaluation of Nevirapine Extended Release Tablets using QbD Approach. Indian Journal of Pharmaceutical Education and Research. 2018;52(4):220-8.

15. Sarraguça MC, Cruz AV, Soares SO, Amaral HR, Costa PC, Lopes JA. Determination of flow properties of pharmaceutical powders by near infrared spectroscopy. Journal of Pharmaceutical and Biomedical Analysis. 2010;52(4):484-92.

16. Sirisolla J, Ramanamurthy KV. Formulation and evaluation of cefixime trihydrate matrix tablets using HPMC, sodium CMC, ethyl cellulose. Indian Journal of Pharmaceutical Sciences. 2016;77(3):321-7.

17. Ahad HA, Kumar BP, Haranath C, Reddy KS. Fabrication and evaluation of glimepiride Cordia dichotoma G. Forst fruit mucilage sustained release matrix tablets. Int J Chem Sci. 2009;7(4):2555-60.

18. Kumar L, Singh V, Meel RK. Formulation and evaluation of gastro retentive floating tablets of terbutaline sulphate. Int J Pharma Sci Res. 2014;5(10):63945.

19. Khan R, Ashraf MS, Afzal M, Kazmi I, Jahangir MA, Singh R, et al. Formulation and evaluation of sustained release matrix tablet of rabeprazole using wet granulation technique. Journal of Pharmacy and Bio Allied Sciences. 2014;6(3):180-5.

20. Chokshi MM, Gupta MM, Gupta MA. Formulation development and evaluation of gastroretentive floating tablet of ciprofloxacin hydrochloride. Int J Pharm Pharm Sci. 2016;8(4):132-7.
21. Prajapati ST, Patel AN, Patel CN. Formulation and evaluation of controlledrelease tablet of zolpidem tartrate by melt granulation technique. ISRN Pharmaceutics. 2011;1(1):1-8.

22. Mahalingan K, Rajarajan S, Baby B, Harsha NS. Formulation and evaluation of clarithromycin extended release tablets. Journal of Pharmaceutical Sciences and Research. 2009;1(3):97-100.

23. Manohari PJ, Seshadri VC, Kunchithapatham J. Extended release tablet formulation of a macrolide antibiotic. Indo American Journal of Pharmaceutical Research. 2017;7(03):8009-19.

24. Rao BS, Kulkarni SV, Patil P, Surpur C. Design and characterization of sustained release aceclofenac matrix tablets containing tamarind seed polysaccharide. Asian Journal of Pharmacy and Technology. 2011;1(1):17-21.

25. Mehta RY, Missaghi S, Tiwari SB, Rajabi-Siahboomi AR. Application of ethylcellulose coating to hydrophilic matrices: A strategy to modulate drug release profile and reduce drug release variability. AAPS Pharm Sci Tech. 2014;15(5):1049-59.

26. Bose A, Wong TW, Singh N. Formulation development and optimization of sustained release matrix tablet of Itopride $\mathrm{HCl}$ by response surface methodology and its evaluation of release kinetics. Saudi Pharmaceutical Journal. 2013;21(2):201-13.

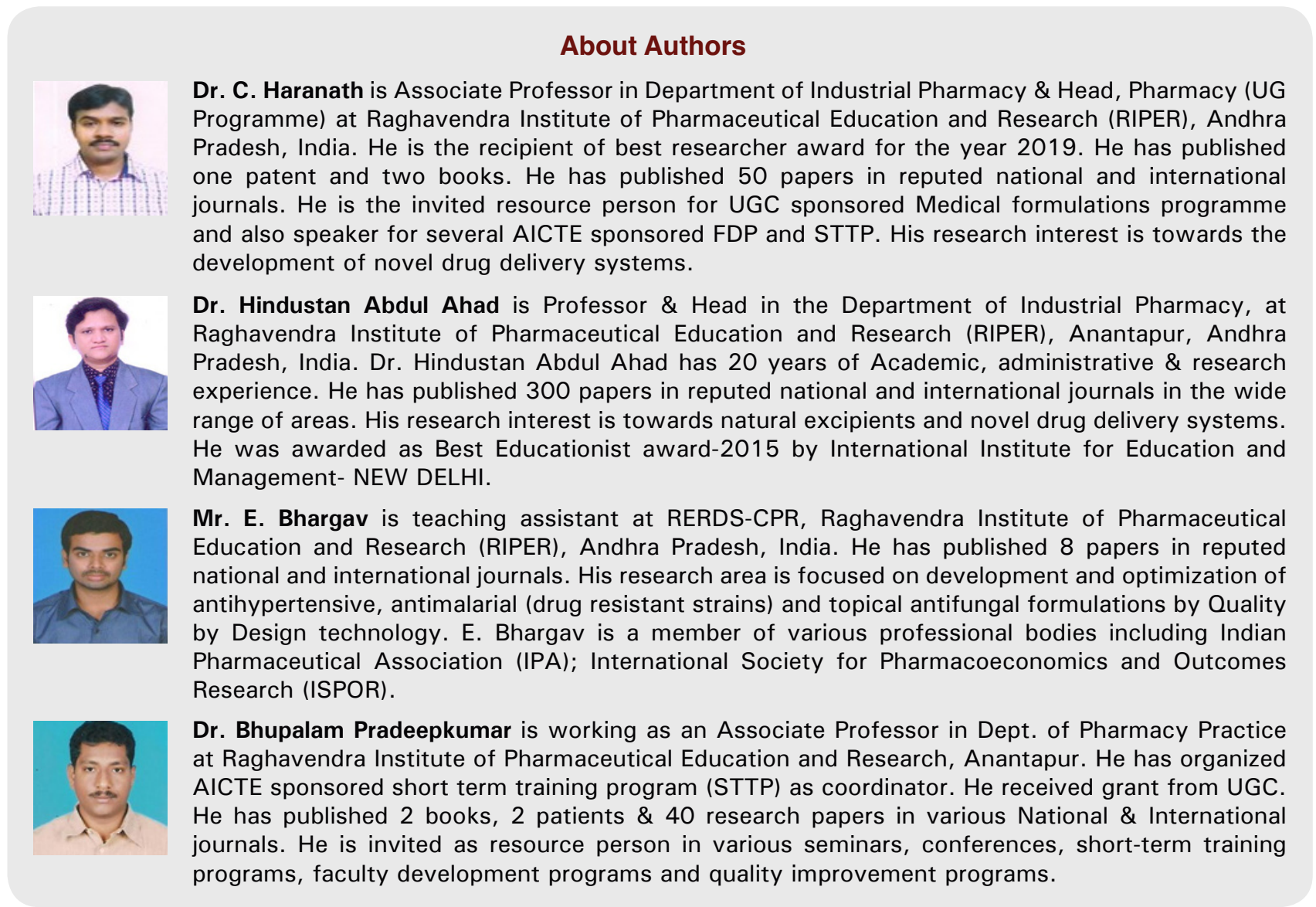


PICTORIAL ABSTRACT

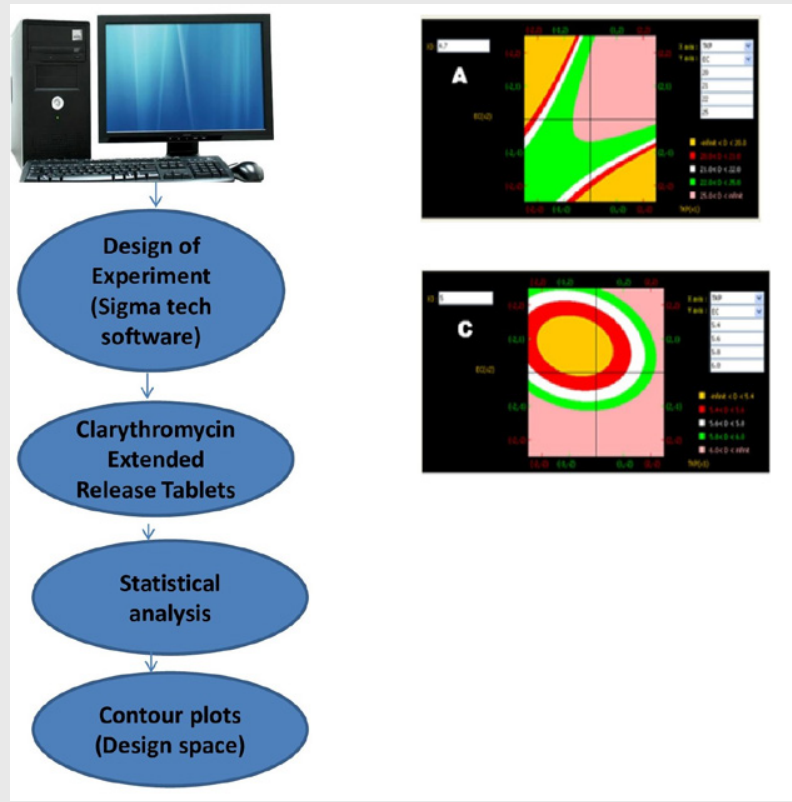

\section{SUMMARY}

- In the present study, clarythromycin extended release tablets were formulated and optimized by using CCD.

- The concentrations of tamarind kernel powder $\left(X_{1}\right)$, ethyl cellulose $\left(X_{2}\right)$ and polyvinyl pyrrolidone $\left(X_{3}\right)$ stayed as non-dependent factors and responses selected were drug release in $2 \mathrm{~h}, 8 \mathrm{~h}$ and $\mathrm{t}_{50} \%$.

- From the results obtained it was inferred that the concentration of independent variables had shown profound effect on dissolution profile.

- Contour designs were utilized to further explicate the bond amid the non-dependent factors and responses. Suitable design space for drug release was found from the contour plots.

Central composite design aided ER tablets

Cite this article: Chinthaginjala H, Ahad HA, Bhargav E, Pradeepkumar B. Central Composite Design Aided Formulation Development and Optimization of Clarythromycin Extended-Release Tablets. Indian J of Pharmaceutical Education and Research. 2021;55(2):395-406. 